\title{
A STUDY ON STRESS MANAGEMENT FACILITIES IN SECONDARY SCHOOLS WITH SPECIAL REFERENCE TO MORIGAON DISTRICT, ASSAM
}

\author{
Jyotika Mohan \\ Research Scholar, Department of Education, Dibrugarh University, Assam, India
}

\begin{abstract}
Stress is one of the unavoidable components of normal life. In this competitive world, adolescents feel stress due to their overburdened activities. According to the 2017 Lancet Report, India has the highest suicide rate between the ages 15-19 years. Between 2010 and 2017, suicide rates per 1,00,000 adolescents increased by 7.9\% per year. The examination and marks oriented education system results in excessive academic stress in students. So if a student feels that he or she is unable to fulfill the demand of parents and teachers, he or she may get stressed. Moderate level stress helps to improve particular task or activity. It finishes work accurately or correctly because of fear or punishment. But increased amount for a prolonged period will have deleterious effect on the physical and mental health and academic achievement of the students. Therefore, it is the major responsibility of every school to provide proper stress management facilities in schools, especially at secondary levels. In this paper an effort has been made to study about the stress management facilities available in secondary schools. This study is based on primary data collected from 10 Government secondary school of Morigaon District, Assam.
\end{abstract}

Key words: Stress, Stress management

Cite this Article: Jyotika Mohan, A Study on Stress Management Facilities in Secondary Schools with Special Reference to Morigaon District, Assam, International Journal of Management, 11(12), 2020, pp 1461-1467.

http://iaeme.com/Home/issue/IJM?Volume $=11 \&$ Issue $=12$

\section{INTRODUCTION}

Stress is one of the unavoidable components of normal life. It is a psychological state. The term stress has been derived from the Latin word 'stringere'; which means 'to draw tight'. The concept of stress was first introduced in life sciences by Hans Selye in 1936. He has defined (1993) stress as, 'Stress is the non specific result of any demand upon the body, be the effect mental or somatic.' Again, according to Lazarus and Folkman (1984), psychological stress is the emotional response experienced when an environmental stimuli or event could 
endanger well-being, is perceived as exceeding a person's resources and can be defined by a stimulus-response relationship. This is based on the cognitive-relational theory of stress which emphasizes that the person-environment interaction is continuous and reciprocal in nature. The degree of stress experienced depends on how much of a stake a person has in the outcome of the event: if there is no relevance to the person and no threat, there will be no stress; if their stake is high, the encounter will pose a threat or challenge, triggering a stress reaction. Hobfoll (1989) believed that stress is a major factor which not only affects people's lives, but also has an impact on their mental and physical health.

Stress management is one of the special techniques which control a person's level of stress. It provides a number of ways to handle chronic stress i.e. keep stress levels within an optimal range and maintain overall well-being. Stress management is understanding stress, recognizing its symptoms holistically and turning it into a positive force using a variety of tools, information and techniques. It is aimed at helping people to deal with the root cause of stress and about the appropriate coping skill to deal with stress. In the broader sense, stress management refers to changing any aspect of the environment or person that will decrease stress and promote health.

Adolescence is a transitional period of life when new and unique stressors are often being encountered such as physical maturation, drive for independence, increased salience of social and peer interactions and brain development. According to Stanely Hall, adolescence is a period of great stresses and strains, storm and strife (Chauhan 1993). Though it may be a time of acute stress for some, it may not always be a stressful time for all. But it is reasonable to assume that a time which is fiery for some is at least smoky for others. It is also true that adolescents owing to quick and colourful changes in all directions naturally experience many problems like social adjustment problem, emotional problem and educational problem. These problems have tremendous effect upon their personality. In India, the examination and marks oriented education system results in excessive academic stress in students. So if a student feels that he or she is unable to fulfill the demand of parents and teachers, he or she may get stressed. Moderate level stress helps to improve particular task or activity. It finishes work accurately or correctly because of fear or punishment. But increased amount for a prolonged period will have deleterious effect on the physical and mental health and academic achievement of the students. Therefore, it is the major responsibility of every school to provide proper stress management facilities in schools, especially at secondary levels.

\section{SIGNIFICANCE OF THE STUDY}

In this competitive world, adolescents feel stress due to their overburdened activities. According to the 2017 Lancet Report, India has the highest suicide rate between the ages 1519 years. Between 2010 and 2017, suicide rates per 1,00,000 adolescents increased by 7.9\% per year. I.V.Lalith Kumari (2013), in her article provides different causes of stress among adolescents such as academic pressure, school environment, extracurricular activities, peers, workload, time management and parental pressure. Now-a-days, broken families like single parent, divorcee parent, frequent conflict between parents or conflict among family members, death of parents etc. also develop emotional and behavioural problems among children. The common symptoms include diminished pleasure in learning, addiction to drugs or alcohol, smoking, irritability, fatigue, depression, insomnia and physical problems, ranging from migraine to back pain and ulcers. (Vivekananda Kendra Yoga Research Foundation,1999). Stressful negative school experiences affect adolescents' academic performance, achievement and social adjustment. An effective mechanism should exist within the societal framework for proper counseling of such students. In this regard, the school can be a suitable place for setting up such a mechanism for help relieve the stress in young minds. 
Considering the above mentioned issues, it is felt that this study will have a significant contribution towards the overall development of students. There are very few researches done in this field and no research has been done on stress management facilities in schools, with special reference to Morigaon district. Therefore, the present study has made an effort to know the stress management facilities in secondary schools of Morigaon District.

\section{REVIEW OF RELATED LITERATURE}

K.G. Kassymova and Agamina Zh. Kundyz (2018) in their article 'Stress in Education' talks about stress management in education, the main causes and symptoms of stress and tips for reducing stress.

K. Ramakrishna Rao and C. Kumar (2017) in their article entitled 'Examination Reforms to Reduce Stress among Students' the authors have defined what is examination stress, its causes and symptoms, and recommendations to reduce examination stress among students.

Dr. Jampa Venkata Rama Chandra Rao (2013) in his research paper 'Stress among Adolescent Students and Management' has identified the causes of stress among adolescent students as well as the remedial measures for stress management.

J.L. Romano(19920) in his article 'Psycho-educational Interventions for stress management and well being' presents examples of ways to introduce stress theory and stress management techniques into existing school curriculum. It is suggested that classroom teachers and counselors can collaborate to offer students knowledge and techniques designed to reduce stress and enhance personal well being.

\section{OBJECTIVE}

To study the stress management facilities in secondary schools of Morigaon District.

\section{METHODOLOGY}

\subsection{Method}

Descriptive Survey Method has been applied for the present study.

\subsection{Population and Sample}

According to educational survey 2018-2019, the total number of secondary schools under Board of Secondary Education, Assam, is 121 and the number of secondary schools under Central Board of Secondary Education is 2 in Morigaon district. Other than these government schools, there are a number of private run schools under the same boards. As the study is based on only the government schools, the population shows only the government schools.

Table 1 Population of the study

\begin{tabular}{|c|c|c|c|c|}
\hline $\begin{array}{c}\text { Total } \\
\text { Secondary } \\
\text { Schools }\end{array}$ & $\begin{array}{c}\text { Total High } \\
\text { Schools }\end{array}$ & $\begin{array}{c}\text { Total } \\
\text { Higher } \\
\text { Secondary } \\
\text { Schools }\end{array}$ & $\begin{array}{c}\text { Total } \\
\text { Madrassas }\end{array}$ & $\begin{array}{c}\text { Govt. } \\
\text { CBSE } \\
\text { Schools }\end{array}$ \\
\hline 121 & 93 & 15 & 11 & 02 \\
\hline
\end{tabular}

(Source: Office record, Inspector of School, Morigaon)

The study was conducted on a sample of 10 secondary schools. Purposive Sampling Method has been applied for the present study. Since there are many secondary schools in the 
remote areas of Morigaon district, the investigators have selected only those schools which are easily accessible. Again, to get better result the investigators have selected 3 Higher Secondary schools, 3 High schools, 2 Madrassas and 2 Govt. CBSE schools.

Table 2 Shows the sample of the study

\begin{tabular}{|c|l|l|}
\hline Sl. No. & \multicolumn{1}{|c|}{ Name of the schools } & \multicolumn{1}{|c|}{$\begin{array}{c}\text { Name of the Principals/ } \\
\text { Headmasters }\end{array}$} \\
\hline 1 & Jagiraod Higher Secondary School & Shri Apurba Das \\
\hline 2 & Jagi Higher Secondary School & Shri Chitraranjan Sarkar \\
\hline 3 & $\begin{array}{l}\text { Central Dharamtul M. } \\
\text { Bora.Higher Secondary School }\end{array}$ & Shri Mukul Barua \\
\hline 4 & Auguri High School & Shri Nitumoni Das \\
\hline 5 & Roumari Secondary School & Shri Bakul Ch. Brahma \\
\hline 6 & Swahid Lakhi Deka High School & Mrs. Ribha Deka \\
\hline 7 & Telahi Islamic Senior Madrassa & Md. Ahmed Ali Sarkar \\
\hline 8 & Sidhaguri Senior Madrassa & Md. Mubarak Ali \\
\hline 9 & Kendriya Vidyalaya & Shri Susil kr. Deman \\
\hline 10 & Jawahar Navodaya Vidyalaya & Shri R.A. Mazumdar \\
\hline
\end{tabular}

Information has been collected from the Principals/Headmasters and two teachers from each school. So the sample includes 30 people.

\subsection{Tools}

For the present study the investigators used Interview Schedule as tool because interview is a two-way method which permits an exchange of ideas and information so that normal and direct conversation is possible. The investigators also personally observed the conditions of the schools.

\subsection{Procedure for Data Analysis}

The collected data was analysed with the help of percentage.

\subsection{Delimitation of the Study}

- The present study has been restricted to Morigaon District, Assam.

- The conclusion of the present study has been derived on the basis of the study of only 10 secondary schools.

\section{ANALYSIS AND INTERPRETATION OF DATA}

Analysis of the availability of stress management facilities:

Facility Regarding Time Management: Time management is a major hurdle for secondary school students. Balancing academics, peer activities and home life can be difficult. School workloads are also very heavy for them. Most of the secondary school teachers $(80 \%)$ have responded by saying that they help the students follow the school routine but are not involved about home affairs unless asked. However, 20\% school teachers have said that they provide appropriate guidance about making balance among their different activities like projects, tuitions, study, co-curricular activities and other family tasks. There is no formal mechanism, 
like home visits by teachers, to help students with their daily activities as found in certain private schools.

Facility to develop optimism among students: Positive thinking helps to decrease the rate of depression and distress. It has been observed that $90 \%$ schools organize different positive discussions among themselves and within the classroom, which help students to cope better with stressful situations and reduces the harmful health effects of stress on their bodies. Teachers also provide motivational guidance to students from time to time. Only one school has reported inviting outside personnel to deliver motivational speech.

Emphasis on nutrition: Nutrition plays a huge role in the ability to manage stress as well as in maintaining health and wellbeing in children. During observation, it has been found that the mid day meal is cooked in very unhygienic conditions in the schools. Not a single school has separate dining hall. Students partake their meal sitting on the verandah floor. Kendriya Vidyalaya has no provision of mid day meals. Jawahar Navodaya Vidyalaya, being a residential school, has no separate provision for mid day meal. But the kitchen and dining hall of this school is far better than the other schools.

Provision for picnic or excursion: Picnic or excursion provides an easygoing environment for relaxation and entertainment of students. Such outings provide opportunities for students to develop social relations, gain practical knowledge regarding those aspects of living which are not included in the curriculum, and for overall personal development. Every year $80 \%$ schools organize picnic or excursion. Only Telahi Islamic Senior Madrassa and Sidhaguri Senior Madrassa schools do not organize any picnic or excursion.

Yoga and meditation facilities: Yoga and meditation helps to keep the mind and body healthy and happy. It also helps to strengthen our immune system. Meditation helps to keep the mind sharp and relieves tension. Most of the schools have yoga and meditation classes. In some schools yoga is an elective subject. In some schools there is a permanent yoga teacher and in others where there is no permanent teacher, an itinerant yoga teacher is provided by RMSA for a cluster of schools. However, Telahi Islamic Senior Madrassa and Sidhaguri Senior Madrassa schools do not have yoga class. All other secondary schools celebrate International Yoga Day every year on 21 st June. This shows that $80 \%$ schools have yoga facility.

Availability of sports facilities: Different types of sports like cricket, hockey, badminton, volleyball etc. keep people physically and mentally fit. These help develop qualities like tolerance, patience, discipline etc. in children. $20 \%$ schools have almost no equipment and infrastructure for holding games and sports. But $60 \%$ schools have certain facilities and equipment of games and sports. Generally, every year in the month of February, all the schools organize annual sports. Most of the schools have NCC as an elective subject. But, Telahi Islamic Senior Madrassa and Sidhaguri Senior Madrassa schools do not have even a playground for children.

Facilities for developing different art forms: Dance, music, poetry, drama, painting etc. are some art forms which help to develop creativity and positive sentiments and feelings. These activities also help people relax and focus. All the secondary schools (100\%) organize different types of cultural activities frequently.

Counseling Facility: School counselor prepares students for academic, career and social challenges. They also encourage students to talk to their parents about the things that they are worried about. When students do not feel comfortable talking about their emotional problems at home, counselors may have individual counseling sessions with them. But professional counseling facilities are not available in any of the secondary schools of Morigaon district. Two schools have reported that in very rare case teachers provide guidance to students. 
Use of humour by the teacher: Use of humour by the teacher plays an important role in reducing classroom stress, providing motivation and developing positive feelings in students. It has been found that $50 \%$ teachers do not use humour in the classroom as they think that it only destroys students' attention. But $50 \%$ teachers use humour which help lighten the atmosphere especially during stressful classes.

\section{FINDINGS}

After analyzing the data the investigators have come to the following findings-

- Some teachers provide students special tips to maintain proper work schedule, which helps them to reduce stress especially, academic stress. But the majority of teachers do not go to the extent of providing advice regarding time management unless asked for.

- Most of the schools do not invite special persons and arrange motivational or inspirational talks for students. But teachers themselves guide the students as and when needed.

- Though schools are providing mid day meal no importance is given to cleanliness and hygiene nor is food selected keeping in mind the needs of the students.

- All the schools organize picnic or excursion, and have yoga facilities except the two Madrassas.

- Yoga and meditation is an elective subject in most of the secondary schools.

- Sports facilities are not up to the mark in almost all the schools.

- All schools organize cultural activities regularly.

- None of the schools have school counselors.

- Only half of the teachers use humour in the classroom.

\section{CONCLUSION AND SUGGESTIONS}

The findings of the present study shows that stress management facilities are inadequate in secondary schools of Morigaon district. The situation is much better in CBSE schools. On the other hand, there is minimum facility available in the Madrassas.

To deal with academic stress among students, it is necessary that the students, parents, teachers, administrators and the government should work hand in hand. Teachers should adopt right methods of teaching using appropriate motivational techniques. The parents also should be encouraged to know and understand the capacities of their children and expect the results accordingly. Good teachers, good parenting, healthy relationships, good environment at school and at home, good peer relationship, positive outlook in life will help any student to face the challenges in life.

\section{REFERENCES}

[1] Best, John W.(1988). Research in Education. Prentice Hall inc, Englewood N.J.

[2] Dash, M.(2000).Education in India. New Delhi: Atlantic Publishers and Distributors.

[3] Fink, G. (2010). Stress: Definition and history. Neuroscience and Biobehavioral Psychology, 1-9. Retrived October 02, 2019 from www.researchgate.net/publication.DOI:10.1016/B978008045046-9.00076-0.

[4] Garret, Henry E. (2007). Statistics in Psychology and education. New Delhi: Paragon International Publishers.

[5] Jyotsna, U. Kavya.(2013).Academic stress on adolescents.Jaipur: Aadi Publications. 
[6] Kothari, C.(2013).Research Methodology. Mumbai: New Age International (P) Limited.

[7] Koul, L.(2013).Methodology of Educational Reseach. New Delhi-110014: Vikas publishing PVT.LTD.

[8] Prabu, P.S. (2015). A study on academic stress among higher secondary students. International Journal of Humanities and Social science Invention, 4(10), 66-68. Retrieved July 05, 2019, from www.ijhssi.org.

[9] Pullokaran, L.J. (2018). Academic stress among college students in Kerala, India. International Journal of Scientific and Research Publications, 8(11) 299-310. Retrieved June 11, 2020, from http://dx.doi.org/10.29322/IJSRP.

[10] Romano, J.L. (1992).Psycho-educational Interventions for stress management and well being. Journal of counseling and development. 71 (2). 199-202.

[11] Singh, S. (1990). Executives under stress. New Delhi: Classical Publishing Company. 